\title{
Effect of different bronchodilators on airway smooth muscle responsiveness to contractile
} agents

\author{
B Gustafsson, C G A Persson
}

\begin{abstract}
"Functional antagonism" is often used to describe the general relaxant effect of bet $a_{2}$ agonists and xanthines and their ability to protect the airways against bronchoconstrictor stimuli. This study in guinea pig isolated trachea addresses the question of whether the capacity of these drugs to protect against constrictor stimuli is related to smooth muscle relaxation. Three antimuscarinic drugs were also examined to determine whether antagonism of mediators other than muscarinic agonists might contribute to bronchodilatation by these antimuscarinic drugs. Terbutaline $(1 \cdot 1$ $\left.\times 10^{-7}, 2 \cdot 2 \times 10^{-7} \mathrm{M}\right)$, theophylline $(2 \cdot 2 \times$ $\left.10^{-4}, 4 \cdot 4 \times 10^{-4} \mathrm{M}\right)$, and enprofylline (5.2 $\left.\times 10^{-5}, 1.0 \times 10^{-4} \mathrm{M}\right)$ relaxed the tracheal tension that remained after indomethacin treatment. They did not, however, alter the carbachol concentration-response curve significantly. In addition, neither theophylline $\left(2.2 \times 10^{-4}\right.$ $M)$ nor terbutaline $\left(1.1 \times 10^{-7} \mathrm{M}\right)$ altered histamine induced contraction. Atropine sulphate, glycopyrrolate, and ipratropium bromide had $\mathrm{EC}_{50}$ values of $10^{-9}$ $10^{-8} M$ for relaxation of carbachol induced contractions, whereas concentrations of $10^{-6}-10^{-3} \mathrm{M}$ or greater were required to relax contractions induced by allergen and nine other non-muscarinic mediators. It is suggested that bronchodilatation by antimuscarinic drugs in vivo is due to inhibition of acetylcholine induced bronchoconstriction alone and that beta $a_{2}$ agonists and xanthines have poor ability to protect airway smooth muscle against constrictor stimuli. Hence mechanisms other than bronchodilatation and "functional antagonism" should be considered to explain the protection against constrictor stimuli in asthma seen with beta agonists and xanthines.
\end{abstract}

Department of Pharmacology, AB Draco, Box 34, S-221 00 Lund B Gustafsson C G A Persson

Department of Clinical

Pharmacology, University Hospital, S-221 00 Lund, Sweden C G A Persson

Reprint requests to: Dr Persson

Accepted 15 February 1991

Three classes of drugs, beta ${ }_{2}$ agonists, xanthines, and antimuscarinics, are known to produce acute bronchodilatation in asthmatic patients. Pharmacological antagonism of muscarinic contraction by antimuscarinic drugs has been amply documented in vitro and in vivo, ${ }^{12}$ but the specificity of action of these drugs against non-muscarinic contractile mediators has not been assessed to any extent. The present study has examined the specificity of muscarinic antagonism by atropine sulphate, ipratropium bromide, and glycopyrrolate in tracheal preparations in vitro against 10 different contractile mediators and allergen. Xanthines and beta receptor $_{2}$ agonists are frequently described as functional mediator antagonists because they relax airway smooth muscle irrespective of the mediator or mediators that caused contraction. ${ }^{3}$ Physiological or functional antagonism has also been the favoured explanation for the protection offered by these drugs against provoked bronchoconstriction in asthmatic subjects, ${ }^{24-9}$ but this has not yet been shown experimentally. Possibly the pharmacology of relaxation is distinct from that of anticonstrictor effects. Indeed, the protective effects of beta ${ }_{2}$ agonists and xanthines in asthma might conceivably result from an effect on cells other than smooth muscle. ${ }^{1011}$ The present study has examined the effect of xanthines and terbutaline on carbachol and histamine induced contraction of guinea pig tracheal preparations, looking at concentrations that produce pronounced relaxant effects in vitro. ${ }^{12-14}$ These drug concentrations are above (about 5-10 times) the blood concentrations seen with systemic treatment (with xanthines and terbutaline), though a similar concentration of terbutaline may be reached in airway smooth muscle tissue after inhalation.

\section{Methods}

AIRWAY SMOOTH MUSCLE PREPARATIONS

Male guinea pigs, weighing $200-300 \mathrm{~g}$, were killed by a blow to the head, and the trachea was dissected out. Two adjoining cartilage rings were cut out and an open tracheal ring was prepared by cutting through the cartilage opposite the muscle. This technique preserves the epithelial lining. ${ }^{13}$ The presence or absence of epithelium is of little or no consequence for the development of spontaneous tension in these preparations ${ }^{13}$ or for determining the relaxant potencies of beta ${ }_{2}$ agonists and xanthines. ${ }^{13}$

The open tracheal ring was mounted in a jacketed, temperature controlled $\left(37^{\circ} \mathrm{C}\right), 25 \mathrm{ml}$ organ bath containing Krebs's solution of the following composition $(\mathrm{mM}): \mathrm{NaCl} 118 \cdot 0, \mathrm{KCl}$ $4 \cdot 6, \mathrm{CaCl}_{2} 2 \cdot 5, \mathrm{MgSO}_{4} 1 \cdot 15, \mathrm{NaHCO}_{3} 24 \cdot 9$, $\mathrm{KH}_{2} \mathrm{PO}_{4} 1 \cdot 15$, and glucose $5 \cdot 5$ with a pH of $7 \cdot 4$ and aerated with $5 \%$ carbon dioxide in oxygen. Change in muscle tension was measured isometrically by a strain gauge transducer (Grass FT03) and recorded on a Grass polygraph (model 7D). The initial mounting tension was adjusted to around $0.5 \mathrm{~g}$. Prepara- 
tions were allowed to stabilise for at least 30 minutes with repeated washings. Drugs were added by injection into the organ baths.

\section{MEASUREMENT OF DRUG EFFECTS}

Theophylline, enprofylline, and terbutaline

These experiments were carried out in the presence of indomethacin $\left(1 \times 10^{-6} \mathrm{M}\right)$ to reduce spontaneous tension so that near maximal to slightly supramaximal relaxant effects could be produced by the beta ${ }_{2}$ agonist and xanthines (the results are similar in the absence of indomethacin; data not shown).

A cumulative concentration-response relationship for carbachol was obtained by increasing the concentration $\left(10^{-8}-10^{-3} \mathrm{M}\right)$ in the bath stepwise until no further response occurred with two consecutive concentrations. The trachea was then washed. Two carbachol concentration-response studies were performed with each preparation to corfirm repeatability. It was then treated with one of the following: theophylline $2.2 \times 10^{-4}$ or $4.4 \times$ $10^{-4} \mathrm{M}$, enprofylline $5.2 \times 10^{-5}$ or $1.0 \times 10^{-4} \mathrm{M}$, or terbutaline $1.1 \times 10^{-7}$ or $2.2 \times 10^{-7} \mathrm{M}$ (these concentrations are known to produce maximal or near maximal relaxant effects in intrinsic tension tracheal ring preparations ${ }^{1213}$ and appreciable relaxation of carbachol contracted preparations $\left.{ }^{14}\right)$. The effect of the relaxant drug was allowed to develop fully for 10-15 minutes, before a third carbachol curve was obtained in the presence of the drug. A cumulative concentration-response relationship for histamine in the presence of indomethacin $\left(1 \times 10^{-6} \mathrm{M}\right)$ was obtained in the same way. A third histamine curve was obtained in the presence of theophylline $2.2 \times 10^{-4} \mathrm{M}$ or terbutaline $1.1 \times$ $10^{-7} \mathrm{M}$.

Atropine sulphate, ipratropium bromide, and glycopyrrolate

Cumulative concentration-response relationships were obtained for atropine sulphate $\left(10^{-8}\right.$ $\left.10^{-3} \mathrm{M}\right)$, ipratropium bromide $\left(10^{-8}-10^{-4} \mathrm{M}\right)$, and glycopyrrolate $\left(10^{-8}-10^{-3} \mathrm{M}\right)$ in preparations precontracted with one of the following mediators: carbachol $\left(6 \times 10^{-7} \mathrm{M}\right)$, histamine $\left(1 \times 10^{-6} \mathrm{M}\right)$, 5-hydroxytryptamine $\left(2 \times 10^{-7}\right.$ $\mathrm{M})$, prostaglandin $\mathrm{F}_{2 \alpha}\left(1.8 \times 10^{-6} \mathrm{M}\right)$, substance $\mathrm{P}\left(3.7 \times 10^{-6} \mathrm{M}\right)$, leukotriene $\mathrm{C}_{4}\left(1 \times 10^{-}\right.$ $\left.{ }^{8} \mathrm{M}\right)$, leukotriene $\mathrm{D}_{4}\left(1 \times 10^{-8} \mathrm{M}\right)$, bradykinin $\left(1 \times 10^{-6} \mathrm{M}\right)$, lys-bradykinin $\left(1 \times 10^{-6} \mathrm{M}\right)$, met-lys-bradykinin $\left(1 \times 10^{-6} \mathrm{M}\right)$. Some tracheal preparations from guinea pigs sensitised to ovalbumin (by intraperitoneal injection of 1 $\mu \mathrm{g}+100 \mathrm{mg}$ aluminium hydroxide in $0.5 \mathrm{ml}$ saline 11 weeks before the experiment) were contracted with ovalbumin $\left(1.5 \times 10^{-9} \mathrm{M}\right)$. We selected a concentration of constrictor drug that caused a tracheal contraction equal to that obtained with the $\mathrm{EC}_{50}$ dose (the concentration producing $50 \%$ of maximal response) of carbachol. Carbachol $6 \times 10^{-7} \mathrm{M}$ was initially added to each trachea to standardise the contraction.

SOURCE AND PREPARATION OF DRUGS

Indomethacin, carbamylcholine chloride (carbachol), ovalbumin grade III, 5-hydroxytryptamine (serotonin), bradykinin, lys- bradykinin, met-lys-bradykinin, and atropine sulphate were obtained from Sigma Chemicals, USA. Terbutaline sulphate, theophylline, and enprofylline were obtained from Draco, Lund, Sweden; leukotriene $\mathrm{C}_{4}$ and leukotriene $\mathrm{D}_{4}$ from Miles Scientific, USA; histamine dihydrochloride from ACO, Sweden; prostaglandin $\mathrm{F}_{2 \alpha}$ (Amoglandin) from Kabi Vitrum, Sweden; substance $\mathbf{P}$ from Peninsula Laboratories, England; ipratropium bromide (Atrovent) from Boehringer Ingelheim, Germany; and glycopyrrolate (AHR-504) from A H Robins, England.

Indomethacin was dissolved in $5 \% \mathrm{NaHCO}_{3}$ before dilution with $0.9 \% \mathrm{NaCl}$. Leukotriene $\mathrm{C}_{4}$ and $\mathrm{D}_{4}$ were dissolved in $70 \%$ ethanol before dilution with phosphate buffer ( $\mathrm{pH} \mathrm{6.9)}$. All other drugs were diluted with saline.

\section{ANALYSIS}

The maximal changes in tension induced by the xanthines, terbutaline, carbachol, and histamine were determined. Relaxation was expressed as a percentage of baseline tension and the response to each concentration of carbachol and histamine as a percentage of the maximal contraction seen in each run with either agonist. Linear regression analysis was performed on three or four points on the linear part of the concentration-response curves, and the $\mathrm{EC}_{50}$ value calculated. $\mathrm{EC}_{50}$ values were log transformed for analysis and geometric mean values are given with SEM in parentheses. A test for the parallellity of the curves was performed on the linear part of the concentration-response curves.

The relaxant response induced by each concentration of the antimuscarinic drug was expressed as a percentage of the maximal relaxation of each mediator induced contraction. Maximal relaxation was determined by adding increasing concentrations of the drug until no further relaxation occurred with two consecutive concentrations. Calculation of $\mathrm{EC}_{50}$ values was as above.

Values in the text represent mean (SEM) values and $n$ refers to the number of animals (that is, preparations) studied. Analysis of variance was carried out and differences between means were examined by Student's $t$ test for paired or unpaired observations. A p value below 0.05 was taken as significant.

\section{Results}

\section{EFFECT OF INDOMETHACIN}

Indomethacin significantly reduced spontaneous basal tension in the tracheal ring preparations before carbachol $(n=36)$ and histamine $(n=30)$ (initial tension: $10.9(0.5)$ and 14.3 $(0.4) \mathrm{mN}$; after indomethacin: 9.3 $(0.4)$ and $11.4(0.5) \mathrm{mN}(\mathrm{p}<0.001))$. The $\mathrm{EC}_{50}$ value for the carbachol concentration-response study in the absence of indomethacin $(5.3 \times$ $\left.10^{-7} \mathrm{M}\right)$ was less than in its presence $\left(2.4 \times 10^{-6}\right.$ $M ; p<0.001$ ), but the maximally induced tension was not altered (data not shown; $\mathrm{p}=$ $0 \cdot 76, \mathrm{n}=72$ ). 
Table 1 Concentrations of carbachol producing tracheal contractions equal to $50 \%$ of the maximal carbachol response $\left(E C_{s 0}\right)$ after pretreatment with different drugs

\begin{tabular}{|c|c|c|}
\hline & $\begin{array}{l}\text { Geometric } \\
\text { mean (SEM) }\end{array}$ & $n$ \\
\hline Control 1 & $2.0 \times 10^{-6}(1.2)$ & 57 \\
\hline Control 2 & $2.4 \times 10^{-6}(1 \cdot 1)$ & 57 \\
\hline Control 3 & $3.1 \times 10^{-6}(1.2)$ & 5 \\
\hline \multicolumn{3}{|c|}{ Drug and concentration $(M)$} \\
\hline \multicolumn{3}{|c|}{ Terbutaline } \\
\hline $1.1 \times 10^{-7}$ & $2.4 \times 10^{-6}(1.2)$ & 12 \\
\hline $2 \cdot 2 \times 10^{-7}$ & $5.1 \times 10^{-6}(1.3)$ & 6 \\
\hline \multicolumn{3}{|l|}{ Enprofylline } \\
\hline $5.2 \times 10^{-5}$ & $2.3 \times 10^{-6}(1 \cdot 1)$ & 12 \\
\hline $1.0 \times 10^{-4}$ & $2.6 \times 10^{-6}(1.2)$ & 6 \\
\hline \multicolumn{3}{|l|}{ Theophylline } \\
\hline $2.2 \times 10^{-4}$ & $4.1 \times 10^{-6}(1 \cdot 1)$ & 12 \\
\hline $4.4 \times 10^{-4}$ & $4.9 \times 10^{-6}(1.1)$ & 6 \\
\hline
\end{tabular}

EFFECTS OF XANTHINES AND TERBUTALINE ON CARBACHOL CONTRACTION

Following indomethacin further relaxation was recorded after the addition of the xanthines and terbutaline. The percentage relaxation produced by terbutaline $\left(1.1 \times 10^{-7}\right.$ and $2.2 \times$ $\left.10^{-7} \mathrm{M}\right)$ was $4.9(1.4)(\mathrm{n}=12)$ and $11.3(2.8)$ $(\mathrm{n}=6)$ respectively, that produced by enprofylline $\left(5.2 \times 10^{-5}\right.$ and $\left.1.0 \times 10^{-4} \mathrm{M}\right) 20.2$ (3.3) $(n=12)$ and $15 \cdot 2(4 \cdot 2)(n=6)$, and that produced by theophylline $\left(2.2 \times 10^{-4}\right.$ and 4.4 $\left.\times 10^{-4} \mathrm{M}\right) 19 \cdot 3(2.5)(\mathrm{n}=12)$ and $24 \cdot 1(6.0)$ $(\mathrm{n}=6)$.

The carbachol concentration-response studies showed good repeatability (table 1). The $\mathrm{EC}_{50}$ values for carbachol obtained in the presence of terbutaline or the xanthines did not differ significantly from the control values (second control run of carbachol: $p>0.05$ table 1). Neither theophylline, enprofylline, or

\section{CONTRACTION(\%)}
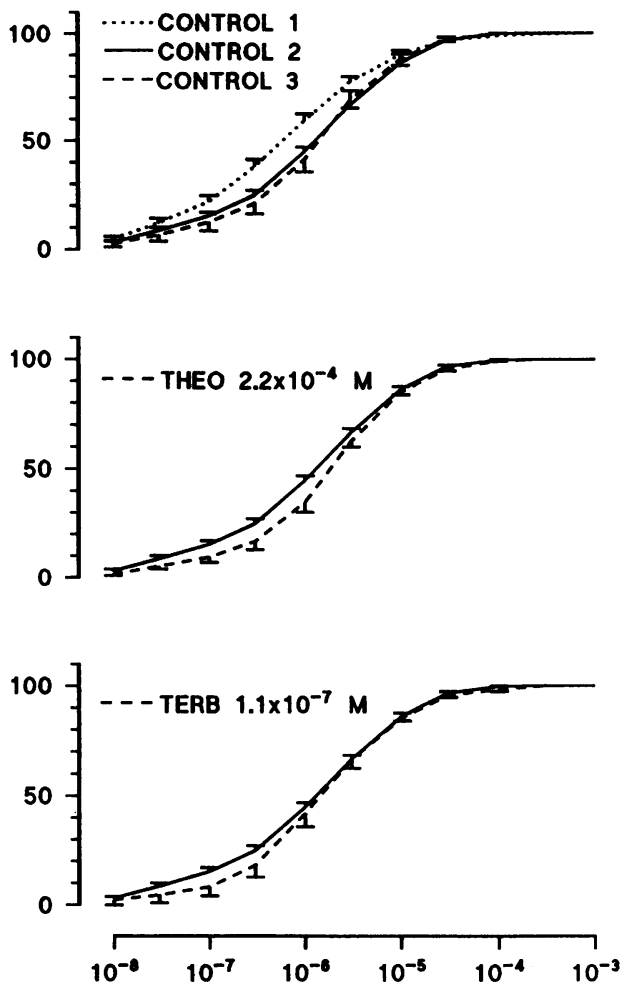

HISTAMINE (mol/l)

Figure 2 Concentration-response curves, showing arithmetic means with SEM (vertical lines), for histamine obtained from tracheal ring preparations in the presence of indomethacin and theophylline (THEO) $(n=12)$, terbutaline (TERB) $(n=12)$, and no drug (CONTROL) $(n=12)$. The top graph shows the mean curves for the first and second control histamine studies $(n=30)$ plus the third $(n=6)$. Response is expressed as percentage of maximal contraction obtained with histamine.

\section{CONTRACTION(\%)}
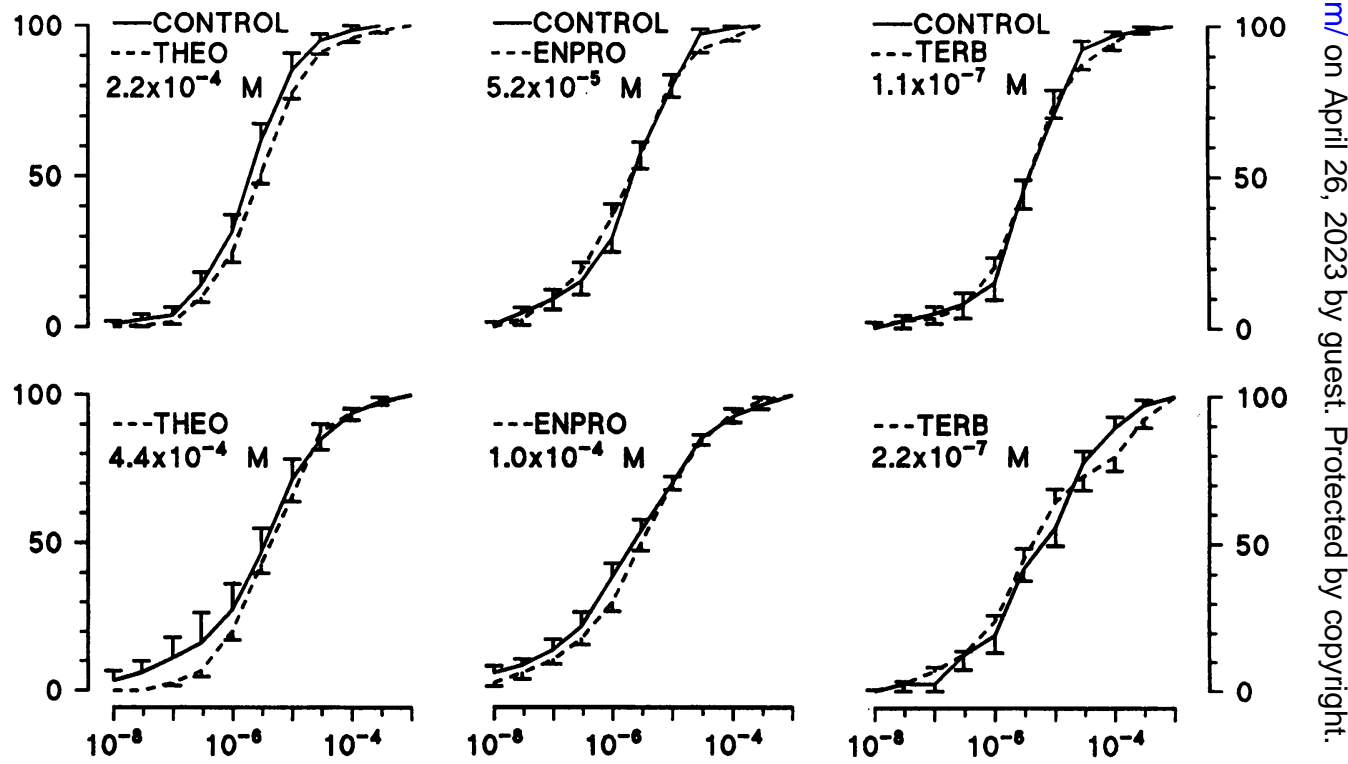

CARBACHOL $(\mathrm{mol} / \mathrm{l})$

Figure 1 Concentration-response curves for carbachol, showing arithmetic means with SEM (vertical lines), obtained from tracheal ring preparations in the presence of indomethacin and theophylline (THEO), enprofylline (ENPRO), terbutaline (TERB), and no drugs(CONTROL). Response is expressed as percentage of maximal contraction obtained with carbachol. 
Table 2 Concentrations of histamine producing tracheal contractions equal to $50 \%$ of the maximal histamine response $\left(E C_{s o}\right)$ after pretreatment with different drugs

\begin{tabular}{|c|c|c|}
\hline & $\begin{array}{l}\text { Geometric } \\
\text { mean (SEM) }\end{array}$ & $n$ \\
\hline $\begin{array}{l}\text { Control } 1 \\
\text { Control } 2 \\
\text { Control } 3 \\
\text { Drug and concentration } \\
\text { value }(\mathrm{M}) \\
\text { Terbutaline } \\
1 \cdot 1 \times 10^{-7} \\
\text { Theophylline } \\
2 \cdot 2 \times 10^{-6}\end{array}$ & $\begin{array}{l}1.2 \times 10^{-6}(1 \cdot 3) \\
1.6 \times 10^{-6}(1 \cdot 2)\end{array}$ & $\begin{array}{r}30 \\
30 \\
6\end{array}$ \\
\hline
\end{tabular}

terbutaline produced any shift of the carbachol concentration-response line (fig 1).

The presence of xanthines or terbutaline did not reduce the maximal tension induced by carbachol. Hence the difference between the lowest (starting tension) and the highest (maximal) tension for the carbachol contraction was larger when carbachol was added to tracheal rings that had been relaxed by a bronchodilator than when it was added to the control preparations $(\mathrm{p}<0.001, \mathrm{n}=54)$. Consequently the $\mathrm{EC}_{50}$ values of carbachol given in table 1 are not directly comparable. Indeed, an unchanged $\mathrm{EC}_{50}$ value suggests that the carbachol induced increase in tension is slightly greater in the presence of a bronchodilator than that observed with the same concentration of carbachol in the absence of the bronchodilator.

\section{EFFECTS OF THEOPHYLLINE AND TERBUTALINE ON HISTAMINE CONTRACTION}

Both terbutaline $1.1 \times 10^{-7} \mathrm{M}$ and theophylline $2.2 \times 10^{-4} \mathrm{M}$ caused relaxation of basal tension (by $6.7 \%(2.3 \%)$ and $23.3 \%(6.7 \%), n=12)$. The initial histamine concentration-response line was further to the left than the second ( $p<$ $0.001)$ and the third $(p<0.05)$ lines; the latter two lines did not differ (fig 2, table 2). The second line was used as the control for subsequent comparisons. Neither theophylline nor terbutaline produced any significant shift of the histamine concentration-response line (fig 2). The mean $\mathrm{EC}_{50}$ values for the histamine concentration-response study in the presence of theophylline $2.2 \times 10^{-4} \mathrm{M}$ and terbutaline $1 \cdot 1$ $\times 10^{-7} \mathrm{M}$ did not differ ( $\left.p>0.05\right)$ from the second control response (table 2 ).

Table 3 Concentrations of atropine sulphate, glycopyrrolate, and ipratropium bromide producing tracheal contractions equal to $50 \%$ of the maximal response $\left(E C_{s_{0}}\right)$ (numbers of preparations in square brackets)

\begin{tabular}{|c|c|c|c|}
\hline \multirow[b]{2}{*}{ Mediator } & \multicolumn{3}{|c|}{$E C_{\text {so }}(M$, geometric mean $(S E M))$} \\
\hline & Atropine & Glycopyrrolate & Ipratropium \\
\hline $\begin{array}{l}\text { Carbachol } \\
\text { Histamine } \\
\text { Serotonin } \\
\text { Prostaglandin } \mathrm{F}_{2 x} \\
\text { Substance } \mathrm{P} \\
\text { Leukotriene } \mathrm{C}_{4} \\
\text { Leukotriene } \mathrm{D}_{4} \\
\text { Ovalbumin } \\
\text { Bradykinin } \\
\text { Lys-bradykinin } \\
\text { Met-lys-bradykinin }\end{array}$ & $\begin{array}{l}3.8 \times 10^{-9}(0 \cdot 5)[6] \\
8.5 \times 10^{-7}(2 \cdot 5)[8] \\
7 \cdot 9 \times 10^{-7}(4 \cdot 0)[7] \\
-[6] \\
-[6] \\
-[8] \\
-[8] \\
-[6] \\
-[12] \\
-[6] \\
-[6]\end{array}$ & $\begin{array}{l}3.8 \times 10^{-9}(0 \cdot 3)[6] \\
5 \cdot 0 \times 10^{-6}(1 \cdot 2)[8] \\
5 \cdot 0 \times 10^{-5}(2 \cdot 2)[7] \\
>1 \times 10^{-3}[6] \\
>1 \times 10^{-3}[5] \\
>1 \times 10^{-4}[7] \\
>1 \times 10^{-3}[8] \\
>1 \times 10^{-3}[12] \\
>1 \times 10^{-3}[10] \\
>1 \times 10^{-4}[6] \\
>1 \times 10^{-3}[6]\end{array}$ & $\begin{array}{l}1.4 \times 10^{-9}(0.4)[6] \\
7.2 \times 10^{-5}(6.0)[4] \\
3.6 \times 10^{-6}(3 \cdot 1)[6] \\
3.5 \times 10^{-5}(0.6)[8] \\
1.1 \times 10^{-5}(1 \cdot 1)[5] \\
2.9 \times 10^{-5}(0 \cdot 4)[5] \\
3.1 \times 10^{-5}(0.6)[5] \\
5.2 \times 10^{-5}(1.9)[5] \\
3.2 \times 10^{-5}(1.0)[9] \\
3.6 \times 10^{-5}(0.9)[5] \\
2.5 \times 10^{-5}(1.6)[3]\end{array}$ \\
\hline
\end{tabular}

The maximal tension induced by histamine was not reduced by theophylline or terbutaline ( $p>0.05$, analysis of variance). The difference between starting tension and maximal histamine induced contraction was therefore larger when histamine was added to tracheal rings that had been relaxed by terbutaline or theophylline than when it was added to control preparations $(p<0.001)$.

EFFECTS OF ATROPINE SULPHATE, IPRATROPIUM BROMIDE, AND GLYCOPYRROLATE

The tracheal ring preparations had a mean tension of $9.0(0.2) \mathrm{mN}$ before administration of drug. Addition of contractile mediators increased the tension to at least $13.7(0.5) \mathrm{mN}$ (bradykinin $1 \times 10^{-6} \mathrm{M}, \mathrm{n}=34$ ) and at most $19 \cdot 6(1 \cdot 3) \mathrm{mN}$ (leukotriene $\mathrm{D}_{4} 1 \times 10^{-8} \mathrm{M}, \mathrm{n}=$ 23). Allergen (ovalbumin) $1.5 \times 10^{-9} \mathrm{M}$ increased the tension to a mean value of 21.2 $(1 \cdot 4) \mathrm{mN}(\mathrm{n}=24)$.

Atropine sulphate, ipratropium bromide, and glycopyrrolate had no effect on the spontaneous tension of untreated preparations given at concentrations below $1 \times 10^{-4} \mathrm{M}$ (concentrations above $1 \times 10^{-4} \mathrm{M}$ produced slight contractions). All three drugs caused pronounced relaxation in preparations precontracted with carbachol. The $\mathrm{EC}_{50}$ values for carbachol contracted trachea were more than 100 times lower than those obtained with the next most effective mediator (table 3 ).

\section{Discussion}

The concentration-response characteristics, including the maximally induced tension, of a muscarinic agonist, carbachol, and histamine were not affected, or were only marginally and inconsistently affected, by the presence of theophylline, enprofylline, or terbutaline. The main effect of relaxation induced by these bronchodilators was to allow carbachol and histamine to cause contraction over a wider tension range. These data suggest that xanthines and beta ${ }_{2}$ receptor agonists may not exert a prophylactic effect at the level of airway smooth muscle. These drugs may be functional antagonists when they relax contracted preparations $^{3}$ but, in the concentrations studied, appear to be without functional antagonism against the initiation and development of airway contraction.

Supramaximal relaxant concentrations of beta ${ }_{2}$ agonists in the airways may protect airway smooth muscle, but whether such concentrations are obtained after inhalation of beta agonists remains to be shown. The concentration of these drugs is probably much larger on the mucosal surface and in the lamina propria than around the smooth muscle as this is deeper in the airway wall. Before reaching the muscle in vivo an inhaled drug has to pass an abundant and extensively perfused microvascular network located just beneath the epithelial lining.

Adenosine was not included in this study because it may not contract the preparations we used. ${ }^{13}$ Adenosine, however, contracts human airway smooth muscle. Theophylline acts on adenosine receptors as a specific antagonist. ${ }^{1015}$ 
Enprofylline, in line with its general lack of adenosine antagonism, does not shift the contractile effect of adenosine in human bronchi. ${ }^{10}$ The particular ability of theophylline to exert a protective effect through adenosine antagonism may not be important. The similar clinical efficacy of enprofylline and theophylline suggests that adenosine antagonism is of little consequence in asthmatic airways. ${ }^{15}$

Interestingly, neither carbachol nor histamine concentration-response curves were shifted by the bronchodilators even though these two agents have different biochemical mechanisms of action. Muscarinic agents inhibit adenylate cyclase ${ }^{16}$ and may thus produce contractions that are particularly difficult to reverse with drugs such as beta agonists, which are believed to act through cyclic AMP production. Both carbachol and histamine produce concentration related increases in inositol phosphates in airway smooth muscle and bronchoconstriction by these agents may depend on hydrolysis of phosphoinositides. ${ }^{1718}$ Beta receptor agonists have been found to inhibit the inositol phosphate response to histamine ${ }^{17}$ but to leave the response to methacholine unaffected. ${ }^{18}$ The concentrations of histamine used in those biochemical studies ${ }^{1718}(0 \cdot 1$ and $1 \mathrm{mM})$ were, however, much larger than those producing a maximum contractile effect in this study, and the biochemical studies were carried out in other species. Hence the present lack of interaction between terbutaline and histamine cannot easily be related to the phosphoinositide hypothesis. We cannot exclude the possibility that contractile mediators other than histamine and carbachol ${ }^{19}$ may be more sensitive to beta ${ }_{2}$ receptor stimulants and xanthines.

We selected a muscarinic agent and histamine because they are widely used for challenges to test airway responsiveness in asthma. ${ }^{20}$ Single dose studies with xanthines and beta ${ }_{2}$ agonists in asthmatic subjects have shown variable bronchodilatation and protection against bronchoconstriction. ${ }^{24-9}$ No correlation has been found between bronchodilatation and protection in individual subjects. This lack of correlation is compatible with the present observations. The protective effect of xanthines and beta ${ }_{2}$ agonists may be due to actions in tissues other than airway smooth muscle. This view is supported by the finding of Britton et $a l^{21}$ that acute bronchodilatation (produced by an inhaled antimuscarinic drug) in itself was not associated with any protection against histamine provocation, whereas the same degree of bronchodilatation induced by

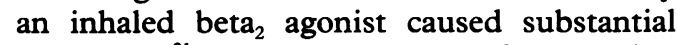
protection. $^{21}$ The mechanism of protection with beta ${ }_{2}$ agonists and xanthines has not been explained, but both drugs have several antiinflammatory effects that may contribute. ${ }^{101122}$

The tension of guinea pig tracheal preparations in vitro has not been fully explained ${ }^{312}$ but is reduced by indomethacin, a drug that inhibits the generation of arachidonate metabolites of the cyclo-oxygenase pathway. ${ }^{1323}$ Indomethacin reduced spontaneous tension. The further relaxant effects of xan- thines and terbutaline appeared to be maximal for theophylline and enprofylline and near maximal for the partial agonist terbutaline. These data are consistent with previous observations on the potency of beta agonists and xanthines in vitro. ${ }^{31-14}$ The $\mathbf{E C}_{50}$ of carbachol was increased by indomethacin. Indomethacin has been associated with reduced sensitivity to several contractile agents in guinea pig trachea ${ }^{2324}$ and, less consistently, in human bronchi in vitro ${ }^{25}$ and in vivo. ${ }^{26}$

Ipratropium bromide, glycopyrrolate, and atropine sulphate did not interact significantly with any mediator other than the muscarinic agonist. The three antimuscarinic drugs caused substantial antagonism of carbachol with a selectivity ratio by comparison with other mediators of at least $10^{2}$. With ipratropium bromide the ratio was more than $10^{3}$. The small interactions that occurred with other mediators are probably of little interest as such concentrations are unlikely to be seen even with large inhaled doses. These data support the view that antimuscarinic drugs antagonise only acetylcholine induced bronchoconstriction in asthma. ${ }^{1}$

The subcellular mechanisms leading to the initiation of contraction differ from those concerned in the maintenance of an established contraction. ${ }^{27}$ As xanthines and beta ${ }_{2}$ agonists reduce established contractions and antimuscarinic drugs inhibit one mediator only, a search for drugs that inhibit the initiation and development of airway smooth muscle contractions may be warranted.

1 Gross NJ, Skorodin MS. Anticholinergic, antimuscarinic bronchodilators. Am Rev Respir Dis 1984;129:856-70.

2 Tattersfield AE. Effect of beta-agonists and anticholinergic drugs on bronchial reactivity. Am Rev Respir Dis 1987; 136:S64-8.

3 Persson CGA, Karlsson JA. In vitro responses to bronchodilator drugs. In: Jenne JW, Murphy S, eds. Drug therapy for asthma. Research and clinical practice. New York: Dekker, 1987:129-76.

4 Cockcroft DW, Killian DN, Mellon JJA, Hargreave FE. Protective effect of drugs on histamine-induced asthma. Thorax 1977;32:429-37.

5 Salome CM, Schoeffel RE, Woolcock AJ. Effect of aerosol and oral fenoterol on histamine and methacholine challenge in asthmatic subjects. Thorax 1981;36:580-4.

6 Koëter GH, Meurs H, Jonkman JHG, de Vries K. Protective effect of choline theophylline on histamine, acetylcholine, and propranolol-induced airflow obstruction. Respiration 1984;45:139-46.

7 McWilliams BC, Menendez R, Kelly HW, Howick J. Effects of theophylline on inhaled methacholine and histamine in asthmatic children. Am Rev Respir Dis 1984;130:193-7.

8 Ellis EF. Inhibition of exercise-induced asthma by theophylline. J Allergy Clin Immunol 1984;73:690-2.

9 Cartier A, Lemire I, L'Archevêque J, Ghezzo H, Martin RR, Malo J-L. Theophylline partially inhibits bronchoconstriction caused by inhaled histamine in subjects with asthma. J Allergy Clin Immunol 1986;77:570-5.

10 Persson CGA, Erjefält I, Gustafsson B. Xanthines-symptomatic or prophylactic in asthma? In: O'Donnell SR, Persson CGA, eds. Directions for new anti-asthma drugs. Basel: Birkhäuser, 1988:137-55.

11 Persson CGA, Erjefält I, Grega GJ, Svensjö E. The role of $\beta$-receptor agonists in the inhibition of pulmonary edema. Ann NY Acad Sci 1982;384:544-57.

12 Karlsson JA, Persson CGA. Influence of tracheal contraction on tracheal relaxant effects in vitro of theophylline and isoprenaline. Br J Pharmacol 1981;74:73-9.

13 Lundblad KAL, Persson CGA. The epithelium and the pharmacology of guinea-pig tracheal tone in vitro. $\mathrm{Br} J$ Pharmacol 1988;93:909-17.

14 Persson CGA, Gustafsson B. Tracheal relaxation from combinations of xanthines and of a $\beta_{2}$-receptor agonist. Lung 1986;164:33-40.

15 Persson CGA. Development of safer xanthine drugs for treatment of obstructive airway disease. J Allergy Clin Immunol 1986;78:817-24. 
16 Jones CA, Madison MJ, Tom-Moy M, Brown JK. Muscarinic cholinergic inhibition of adenylate cyclase in airway smooth muscle. Am J Physiol 1987;253:C97-104.

17 Hall IP, Hill SJ. $\beta$-Adrenoceptor stimulation inhibits histamine-stimulated inositol phospholipid hydrolysis in bovine tracheal smooth muscle. Br J Pharmacol 1988; bovine trachea

18 Madison JM, Brown JK. Differential inhibitory effects of forskolin, isoproterenol, and dibutyryl cyclic adenosine monophosphate on phosphoinositide hydrolysis in canine tracheal smooth muscle. $J$ Clin Invest 1988;82:1462-5.

19 Hay DWP, Muccitelli RM, Wilson KA, Wasserman MA, Thorphy TJ. Functional antagonism by salbutamol suggests differences in the relative efficacies and dissociation constants of the peptidoleukotrienes in guinea pig trachea. $J$ Pharmacol Exp Ther 1988;244:71-8.

20 Hargreave FE, Woolcock AJ, eds. Airway responsiveness: measurement and interpretation. Mississauga: Astra Pharmaceuticals Canada, 1985:1-146.

21 Britton J, Hanley SP, Garrett HV, Hadfield JW, Tattersfield AE. Dose related effects of salbutamol and ipratropium bromide on airway calibre and reactivity in subjects with asthma. Thorax 1988;43:300-5.
22 Persson CGA, Pauwels R. Pharmacology of antiasthma xanthines. In: Page C, Barnes PJ, eds. Pharmacology of asthma. (Handbook of experimental pharmacology. Vol 98.) Berlin: Springer, 1991:207-25.

23 Farmer JB, Farrar DG, Wilson J. Antagonism of tone and prostaglandin-mediated responses in a tracheal preparation by indomethacin and SC-19220. Br J Pharmacol tion by indome

24 Orehek J, Douglas JS, Bouhuys A. Contractile responses of the guinea-pig trachea in vitro: modification by prostaglandin synthesis-inhibiting drugs. $J$ Pharmacol Exp Ther 1975;194:554-64.

25 Brink C, Grimaud C, Guillot C, Orehek J. The interaction between indomethacin and contractile agents on human isolated airway muscle. Br J Pharmacol 1980;69:383-8.

26 Kirby JG, Hargreave FE, O'Byrne PM. Indomethacin inhibits allergen-induced airway hyperresponsiveness but not allergen-induced asthmatic responses [abstract]. $\mathrm{Am}$ Rev Respir Dis 1987;135:A312.

27 Rodger IW. Calcium ion mechanisms in airway smooth muscle: potential targets for novel symptomatic drugs for asthma. In: O'Donnell SR, Persson CGA, eds. Directions asthma. In: O'Donnell SR, Persson CGA, eds. Directions
for new anti-asthma drugs. Basel: Birkhäuser, 1988:69-87. 